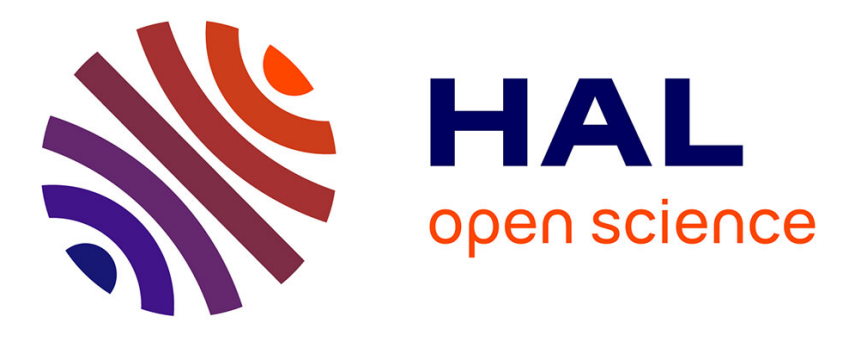

\title{
Mechanical characterization of tropical glued solid timber beams
}

Cédrick Horphé Ndong Bidzo, Rostand Moutou Pitti, Samuel Ikogou, Beat Kaiser

\section{- To cite this version:}

Cédrick Horphé Ndong Bidzo, Rostand Moutou Pitti, Samuel Ikogou, Beat Kaiser. Mechanical characterization of tropical glued solid timber beams. SEMC 2019: The Seventh International Conference on Structural, Sep 2019, Cap Town, South Africa. hal-02116760

\section{HAL Id: hal-02116760 \\ https://hal.science/hal-02116760}

Submitted on 1 May 2019

HAL is a multi-disciplinary open access archive for the deposit and dissemination of scientific research documents, whether they are published or not. The documents may come from teaching and research institutions in France or abroad, or from public or private research centers.
L'archive ouverte pluridisciplinaire HAL, est destinée au dépôt et à la diffusion de documents scientifiques de niveau recherche, publiés ou non, émanant des établissements d'enseignement et de recherche français ou étrangers, des laboratoires publics ou privés. 


\title{
Mechanical characterization of tropical glued solid timber beams
}

\author{
C.H. NDONG BIDZO \\ Ecole Nationale des Eaux et Forêts, LaReVa Bois, BP 39 Libreville, Gabon
}

R. MOUTOU PITTI

Université Clermont Auvergne, CNRS, SIGMA Clermont, Institut Pascal, BP 10448, F-63000 Clermont-

Ferrand, France

CENAREST, IRT, BP 14070, Libreville, Gabon

S. IKOGOU

Ecole Polythechnique de Masuku, BP 901 Franceville, Gabon

B. KAISER

Ecowood SA, BP 4016, Libreville Gabon

\begin{abstract}
This paper deal with the mechanical behavior of some tropical glued species. Three tropical species have been correctly selected from four criteria (threat of extinction, availability, resistance and job class). The goal is to manufacture glued solid timber beams from hardwood (Staudtia kamerunesis And Ppterocarpus soyauxii) and softwood (Dacryodes Buettneri), the adhesive used is at the phenol. The rupture module (MoR) and the modulus of elasticity (MoE) of four configurations are calculated and compare to the characteristics of soft wood. The results show the increasing in the strength and the stiffness of the beams made of Staudtia kamerunesis and Dacryodes Buettneri relative to the characteristics of the soft wood. While the characteristics of beams made up of Ppterocarpus soyauxii and Dacryodes Buettneri Slightly below the characteristics of the soft wood.
\end{abstract}

\section{INTRDUCTION}

In Gabon, forest covers about $85 \%$ of the territory. From the perspective of an emerging Gabon, the government has decided to ban the export of logs since January 2010, paving the way for local processing and extension of tropical species in local and sub-regional constructions (Ikogou et al. 2016). However, because of the operating costs related to primary processing and drying, the massive sawn timber used in construction are still very expensive. An alternative would be to use Glued solid timber (GST) and Glued Laminated Timber (GLT) from different species in order to minimize sawing losses, maximize the mechanical strength of the structural elements obtained and to control. Consequently, the costs of timber construction are considered high in view of the large forest resources available in the country.

Only GST, for example, are beneficial because of their technical, economic and ecological efficiency. They are mainly used in temperate countries in the construction of larges structures. Indeed, the current standards are written only for softwood species and the design and manufacturing recommendations rely on experimental tests on softwoods (Tran 2014).

In this study, three species of wood were reasonably selected through a multi-criteria analysis in order to achieve the set objectives. The individual lamellae were characterized by three-point flexural tests. A phenol adhesive was used for binding the beams, the GST DUO and TRIO beams were characterized by three-point bending tests to study the different combinations.

\section{MATERIAL AND METHODS}

In order to perfectly glue the lamellae during the construction of reconstituted solid wood beams, the study was based on 40 species with a good ability to glue beforehand (CIRAD 2011). Four criteria were retained for the final choice of species: (i) the threat of extinction, (ii) the availability wood, (iii) the employment class and (iv) the mechanical resistance. Intra-criterion and inter-criterion weights were performed using a scale of 1 to 5

The results of the multi-criteria analysis resulted in the choice of Dacryodes Buettneri (Ozigo),Staudtia kamerunesis (Niové) and Ppterocarpus soyauxii (Padouk).

\subsection{Preparation of specimens}

The already dried wood was supplied and sized by Ecowood SA. The humidity of the wood was $17 \%$ for Ozigo and $14 \%$ for Padouk and Niové. The single 
Iamellae were tirst manutactured. I he adnesive used for the binding was phenol ("Aerodux 185"). Before proceeding in the binding activity for the construction of the GST beams, boards were planed according to figure 1-a. to a final thickness of $20 \mathrm{~mm}$ for the TRIO and $30 \mathrm{~mm}$ for the DUO. The grammage (Fig 1b.) was done manually and on one side. The planks were stacked and put on the press with a pressure during $24 \mathrm{~h}$, with different combinations of the GST composed of numerous species (Fig. 1d)

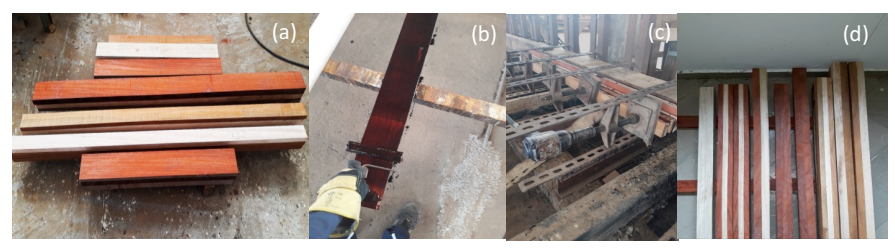

Figure 1. Gluing process: (a) boards planed, (b) grammage, (c) Presse, (d) GST beams.

\subsection{Methods}

In this work, the tests were carried out on a UNITED testing machine fitted with a maximum load cell of $100 \mathrm{KN}$, the data were retrieved by the Datum software and processed on Excel. The tests were performed in a room with average temperature of $25^{\circ} \mathrm{C}$ and relative humidity of $65 \%$. Before the test, the humidity of the specimens was reduced to $12 \pm$ $4 \%$ in a climate chamber.

The three-point bending tests were carried out on single slats and the GST (fig. 2) was performed according to EN 408 (AFNOR 2009).

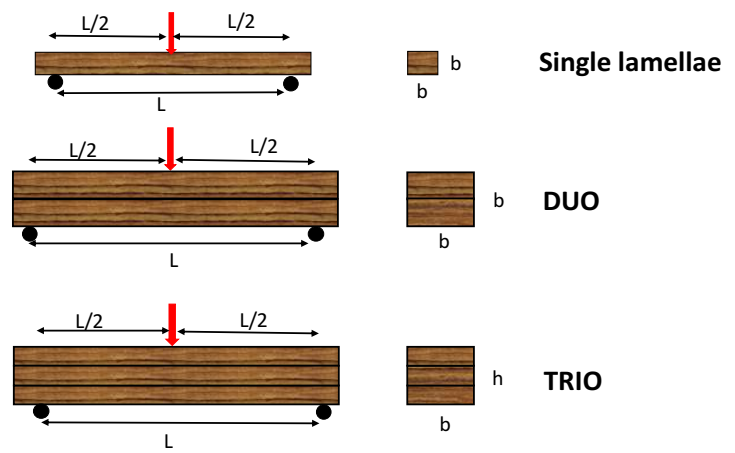

Figure 2. Different types of the tested beams on three-point bending.

\section{EXPERIMENTAL RESULTS}

For better follow-up of the test specimens during the data, the Niové is noted Ni, the Padouk Pdk and the Ozigo Oz.

The MoR and MoE averages were calculated for the singles lamellaes and multi-gasoline RSWs, to determine the best DUO and TRIO combinations.
I he strongest combinations were N1-UZ and N1-UZ$\mathrm{Ni}$ with a MoE of (12476 MPa) and (14924 MPa) respectively. Brittle rupture was noted at the level of the Padouk lamellae and a ductile rupture on the slats of Niové. Table 5. Shows the values of the MoR and $\mathrm{MoE}$ of the various specimens tested.

Table 5. Values of experimental characteristics.

\begin{tabular}{lcccc}
\hline Specimens & Number & $\begin{array}{c}\text { Humidity } \\
\%\end{array}$ & $\begin{array}{c}\text { MoR } \\
\mathrm{MPa}\end{array}$ & $\begin{array}{c}\mathrm{MoE} \\
\mathrm{MPa}\end{array}$ \\
\hline Ozigo & 4 & 12.5 & 74 & 11746 \\
Padouk & 5 & 13 & 136 & 15614 \\
Niové & 5 & 13 & 133 & 18856 \\
Ni-Oz & 3 & $13.5-12.6$ & 79 & 12476 \\
Pdk-Oz & 2 & $12.5-13$ & 68 & 11013 \\
Ni-Oz-Ni & 3 & $13-12-12.3$ & 111 & 14924 \\
Pdk-Oz-Pdk & 3 & $12.5-13-12.6$ & 77 & 10183 \\
\hline
\end{tabular}

\section{DISCUSSION AND CONCLUSION}

Niové, Padouk and Ozigo were classified into resistance classes D70, D65 and D35 in accordance with those of hardwoods of EN 338 (AFNOR 2016) standard. The TRIO Ni-Oz-Ni (14924 MPa) combination we obtain the most fracture toughness; it could be classified according to EN 14080 standard (AFNOR 2005) to belong to the highest resistance class (GL 32h). This configuration would be reasonable in the choice of structural use, as its characteristics are like that of hardwood (Padouk).

It is pointed out, however, that by associating the Padouk (hardwood) and the Ozigo (soft wood), the resistance and stiffness of the beams (DUO and TRIO) tested is almost the same with that of the simple lamellae of Ozigo.

\section{REFERENCES}

AFNOR. 2005. Wood structure-Glued laminated timber and glued solid timber-Exigences. Standard EN 14080, Afnor edition.

AFNOR. 2009.. Wood structure - Structural timber and Glued laminated timber - Determination of certain physical and mechanical properties. Standard EN 408, 2016.

AFNOR. 2016. Struvtural wood : Resistance class. Standard EN 338, Afnor edition.

CIRAD. 2011. Technological characteristics of 245 tropical and temperate species. Bases of databases of forest species, Tropix 7.

Ikogou S. and al. 2016. Experimental study of tropical wood under cyclic compressive loading for sustainable constructions. World Conference of Timber Engineering (WCTE 2016), Vienna, Austria.

Tran, V.D. 2014. Characterization and numerical modeling of glued solid timber beams (GST) made with a hardwood tree. Thesis, Université Lorraine. 